\title{
The horse equipment of the ancient nomads by the images on the monuments of art
}

\author{
Akhmetzhan Kaliolla Samatuly \\ Candidate of History, senior researcher of the A. Margulan Branch Archeology Institute in Astana. \\ Address: Astana, Ryskulbekova str.7, apt. 87. E-mail: kaliolla.akhmetzhan@mail.ru.
}

\begin{abstract}
The types of the horse equipment applied by ancient nomads in the daily purposes, which differed from the harness, found in archaeological studied burials of noble soldiers and leaders are considered in the article. The matter is that the harness found in burials was used for the ceremonial and ritual purposes. It differs in existence of perfectly decorated with gold, felt covers, decorative pendants.

Source of reconstruction of daily horse equipment are its images on various artifacts found in different regions of residence of nomads. Based on the analysis of these images the author carries out reconstruction of appearance and manufacturing techniques of a daily horse harness (bridles, saddles, a saddle and accessories). In the analysis of various images made by different handicraftsmen during the different periods of time the bright similarity of a horse harness is found in nomads of East Kazakhstan, South Kazakhstan, Central Asia, Altai, North China and also it demonstrates that the general traditions and technologies of its production remained in the specified region during two-three and even more centuries. Comparison of archaeological materials demonstrates that such sets of daily horse tackles became prototypes of solemn and ritual horse equipment over time.

Keywords: images of antiques saddles; images of horse tack and equipment; antique saddle; Scythian soft saddle; household horse tack and equipment; daily horse tack and equipment; equipment for horseback; saddle accessories; saddle straps and reins; saddle pendants; horse bridles; saddle of ancient nomads; saddle manufacturing technology; reconstruction of horse tack equipment.
\end{abstract}

\section{Ежелгі көшпенділердің ат әбзелдері өнер ескерткіштеріндегі бейнелер бойынша}

\section{Ахметжан Қалиолла Саматұлы}

тарих ғылымдарының кандидаты, ҚР БҒМ ҒК Астана қаласындағы Ә.Х.Марғұлан атындағы археология Институты филиалының бас ғылыми қызметкері. Мекен жайы: Астана қ, Рысқұлбеков үйі 7, 87 үй. E-mail: kaliolla.akhmetzhan@mail.ru.

Аңдатпа. Мақалада археологиялық қорымдарда жерленген жауынгерлердің және көсемдердің ежелгі көшпенді өмірде күнделікті қолданылған ат әбзелдерінің түрлері қарастырылған. Қорымнан табылған ат әбзелдері әдет-ғұрып және салттық мақсаттарда пайдаланылған. Ол тамаша алтынмен, киіз қаптамалармен, сәндік алқалардың болуымен ерекшеленеді.

Қайта жаңартылатын күнделікті ат әбзелдерінің дереккөзі көшпенділердің түрлі аймақтарында табылған тарихи жәдігерлердегі бейнелер болып табылады. Осы суреттерді талдау негізінде автор ат әбзелдерінің сыртқы түрін және жасау технологиясын реконструкциялауды жүзеге асырады (ауыздық, ер-тұрман, ер және аксессуарлар). Талдау кезінде әр түрлі уақыт кезеңдерінде әр түрлі шеберлермен дайындалған әр түрлі суреттер арқылы Шығыс Қазақстан, Оңтүстік Қазақстанның, Орта Азияның, Алтайдың, Солтүстік Қытайдың аумағын мекен-деушілердің өндіріс дәстүрлері мен технологияларының ат әбзелдерінің жарқын ұқсастықтары өз кезегінде мұндай ұқсастықтардың екі-үш, тіпті одан да көп ғасырларда сақталғандығын дәлелдейді. Археологиялық материалдарды салыстыру көрсеткендей, дәл осындай күнделікті жинақтар болашақта ат әбзелдері құралдарының салтанатты және салт жоралар жабдықтары прототипы болды.

Кілт сөздер: ежелгі ер тоқымның суреті; ат әбзелінің суреті; ежелгі ер тоқым; скифтік жұмсақ ертоқым; тұрмыстық ат әбзелдері; тұрмыстық ат әбзелдері; мінетін ат әбзелдері; ершікті белбеулер; ершікті аспа; қалқан тәріздес аспа; жүген; аттың жүгені; ежелгі көшпенділердің ер-тоқымы; ертоқым жасау технологиясы; реконструкция.

\section{Конское снаряжение древних кочевников по изображениям на памятниках искусства}

\section{Ахметжан Калиолла Саматулы}

кандидат исторических наук, старший научный сотрудник Филиала Института археологии имения А.Х. Маргулана в г. Астане. Адрес: г. Астана, ул Рыскулбекова дом 7, кв 87. E-mail: kaliolla.akhmetzhan@mail.ru. 
Аннотация. В статье рассматриваются типы конного снаряжения, применявшегося древними кочевниками в повседневных целях, которые отличались от упряжи, обнаруженной в археологически исследованных захоронениях благородных воинов и вождей. Дело в том, что упряжь, обнаруженная в захоронениях, употреблялась для обрядовых и ритуальных целей. Оно отличается наличием великолепно украшенных золотом, войлочных чехлов, декоративных подвесок. Источником реконструкции повседневного конского снаряжения являются его изображения на различных артефактах, обнаруженных в разных регионах проживания кочевников. На основе анализа этих изображений автор осуществляет реконструкцию внешнего вида и технологий изготовления повседневной конской упряжи (уздечки, седла, седла и аксессуаров). При анализе различных изображений, изготовленных разными ремесленниками в разные периоды времени, обнаруживается яркое сходство конской упряжи у кочевников Восточного Казахстана, Южного Казахстана, Средней Азии, Алтая, Северного Китая, а также это свидетельствует о том, что общие традиции и технологии его производства сохранялись в указанном регионе в течение двух-трех и даже более веков. Сопоставление археологических материалов свидетельствует о том, что такие именно такие комплекты повседневных конных снастей со временем стали прототипами торжественного и ритуального конного снаряжения.

Ключевые слова: изображение древнего седла; изображение конского снаряжения; древнее седло; скифское мягкое седло; бытовое конское снаряжение; повседневное конское снаряжение; снаряжение верхового коня; седельные принадлежности; седельные ремни; седельная подвеска; щитовидные подвески; узда; конская узда; седло древних кочевников; технология изготовления седла; реконструкция конского снаряжения.

\title{
ӘОЖ/ УДК 902/904
}

\section{Конское снаряжение древних кочевников по изображениям на памятниках искусства}

\author{
Ахметжан К.С.
}

По материалам археологических раскопок достаточно хорошо изучено конское снаряжение (узда, седло и седельные принадлежности) древних кочевников - древних обитателей Алтая. Эти образцы конского убора, найденные в царских курганах и в захоронениях знатных вождей, очень богато украшены пышным декором, потому что в большинстве случаев они являлись церемониальными, а некоторые - ритуальными и не применялись древними кочевниками в повседневном быту. Составные части и технология изготовления, а также декор элементов такого конского снаряжения достаточно подробно описаны в научной литературе (в работах С.И. Руденко, М.П. Грязнова, Н.В. Полосьмак, 3. Самашева, Е.В. Степановой и других авторов). При этом, исследователями до сих пор мало обращалось внимания на повседневное бытовое снаряжение для верхового коня, использовавшееся древними кочевниками Алтая и прилегающих территории.

Такое верховое конское снаряжение достаточно часто изображается на памятниках искусства самих кочевников, что позволяет увидеть некоторые особенности. Несмотря на частое использование в научных публикациях прорисовок этих изображений, подробного изучения их в совокупности до сих пор не было. В этой статье, на основе изобразительных источников, будет рассмотрено повседневное конское снаряжение, применявшиеся древними кочевниками, обитавшими от Восточного Казахстана до Северного Китая.

Изобразительными источниками для изучения этого вопроса были использованы:

1) Парные Р-образные золотые пластины-застежки с изображением сидящих под деревом людей из Сибирской коллекции Петра І. Государственный Эрмитаж. Санкт-Петербург. V-III вв до н.э. (Рисунок 1). 


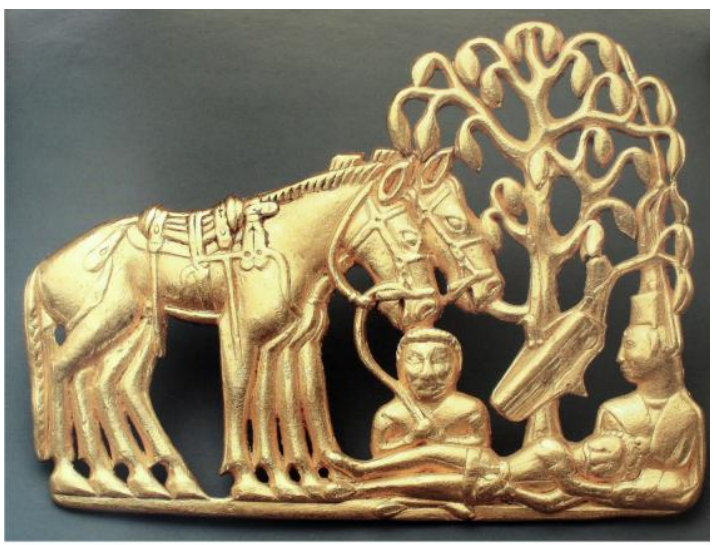

1

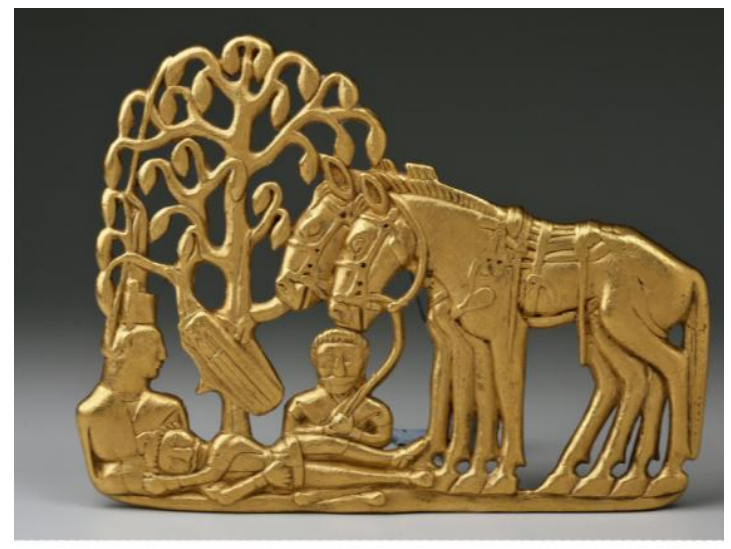

2

Рисунок 1. Парные золотые пластины-застежки с изображением сцены отдыха под деревом из Сибирской коллекции Петра I.

Государственный Эрмитаж. Санкт-Петербург. V-III вв до н.э. Восточный Казахстан ${ }^{1}$

2) Парные Р-образные золотые пластины-застежки с изображением сцены охоты на кабана из той же коллекции. Государственный Эрмитаж. Санкт-Петербург. III-II вв. до н.э (Рисунок 2). Обе эти парные золотые пластины-застежки из Сибирской колллекции были раскопаны «бугровщиками» (кладоискателями) в XVIII веке из курганов, расположенных в степной полосе Сибири между реками Иртыш и Обь. Ныне это восточная часть Казахстана и Кулундинская степь Алтайского края (Руденко 1962, С.12,13).
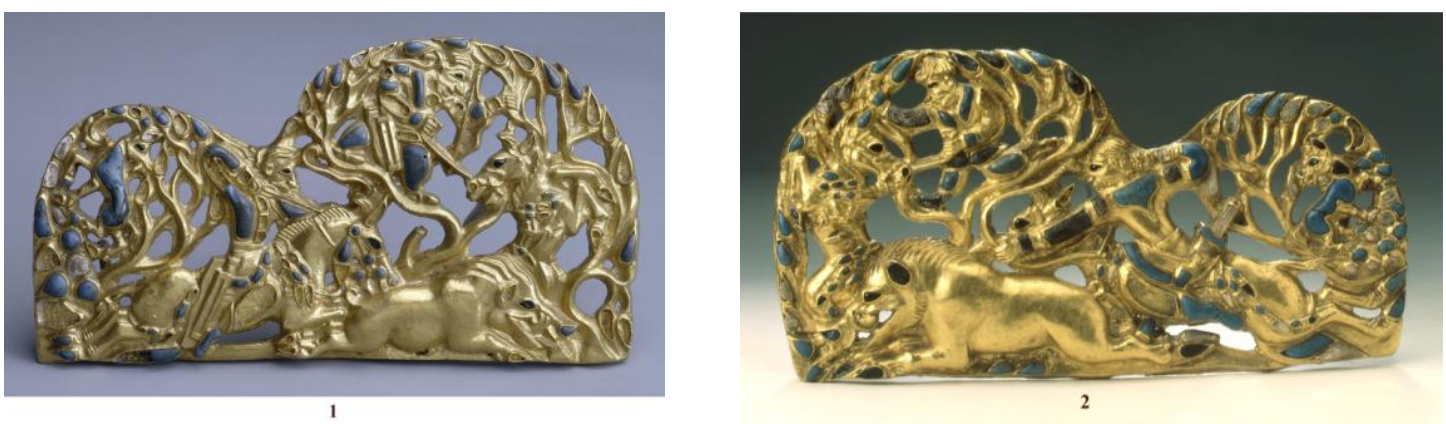

Рисунок 2. Парные золотые пластины-застежки с изображением сцены охоты на кабана из Сибирской коллекции Петра I.

Государственный Эрмитаж. Санкт-Петербург. III-ІІ вв до н.э. Восточный Казахстан ${ }^{2}$

3) Бронзовые поясные бляхи с изображением сцены борьбы спешившихся всадников (Рисунки 3 и 4), найденные в Ордосе, в Северном Китае. Одна из пластин из частной коллекции (Рисунок 3:1) (Jenny 1995, plate 1, Р.22). Другая пластина (Рисунок 3:2) из коллекции Музея Виктории и Аль-берта в Лондоне (фото из интернета). Прорисовки двух таких бронзовых пластин (Рисунок 4) были опубликованы М.П. Грязновым (Грязнов 1661, рис.3, С.11). Пластины по времени относятся к III-II вВ. до н.э. и атрибутируются как хуннские. Все эти бронзовые бляхи схожи во всех деталях, но являются поздними копиями одного ран-

\footnotetext{
${ }_{1}^{1}$ Сайт Государственного Эрмитажа: https:/www.hermitagemuseum.org/wps/portal/hermitage/digital-collection

${ }^{2}$ Сайт Государственного Эрмитажа: https://www.hermitagemuseum.org/wps/portal/hermitage/digital-collection
} 
него образца, и сделаны, видимо, в разное время, в разных местах. Исследователи относят их к изделиям восточной группы кочевников III-I вB. до н.э., которые были в составе державы хуннов (Грязнов 1961, С.0-11; Рец 2004, С.331).
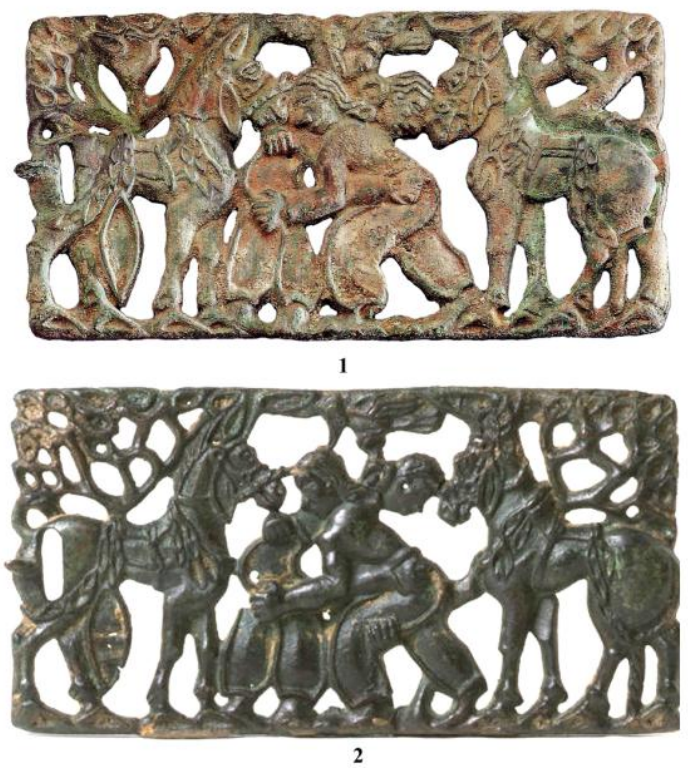

Рисунок 3. Парные бронзовые поясные пластины с изображением борьбы спешившихся всадников. Ордос, Северный Китай. 1 - Из частной коллекции.

2- из Музея Виктории и Альберта. Лондон (из интернета). III-ІІ вв. до н.э.
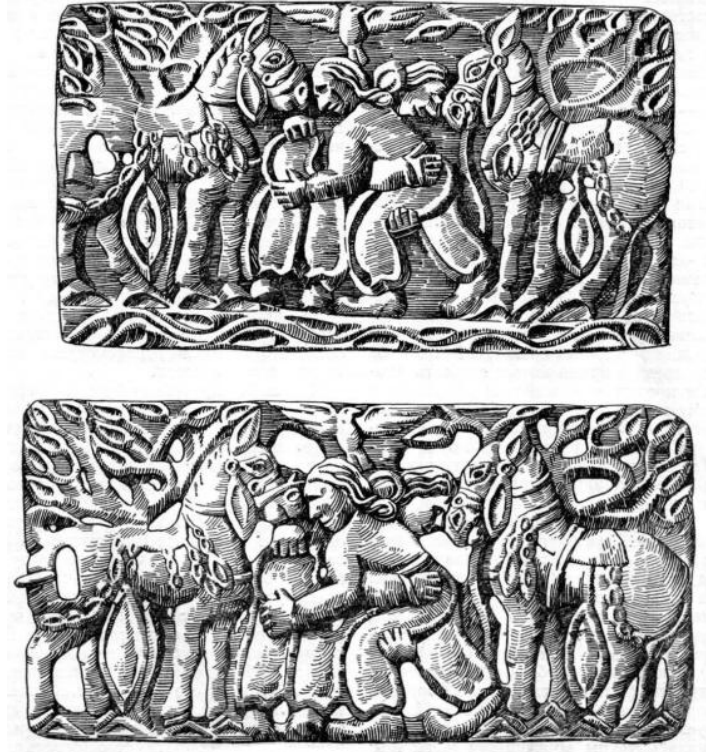

Рисунок. 4. Парные бронзовые поясные пластины с изображением борьбы спешившихся всадников. Ордос, Северный Китай. Прорисовка по оригиналу. По М.П.Грязнову. III-ІІ вв. до н.э.

4) Изображение всадника на войлочном ковре (Рисунок 5:1) и изображения всадников на ворсовом шерстяном ковре из Пятого Пазырыкского кургана (Рисунок 5:2). Государственный Эрмитаж. Санкт-Петербург. V-III вв до н.э.

Выбор именно этих произведений искусства, как источника для изучения, определено тем, что на них достаточно полно и подробно показано конское снаряжение, а также во всех этих произведениях прикладного искусства древние кочевники изображены во время своей повседневной деятельности: в поездке, в момент отдыха, состязаний, на охоте, и т.д. Поэтому изображенное верховое конское снаряжение можно оценивать как повседневное. Несмотря на большой хронологический охват, выбор этих произведений обусловлен также и схожестью технологий изготовления снаряжений и схожестью их форм.

5) Для аналогии и сравнения использовались: скульптурное изображение лошади с седлом из гробницы древнекитайского императора Цинь Шихуанди (Рисунок 6:1,2) III в. до н.э.; археологические материалы из пазырыкских курганов и других курганов пазырыкского периода (Рисунок 6:3,4); а также изображения на костяных поясных пластинах из Орлатского кургана №2 в Средней Азии (Рисунок 7) III-II вв. до н.э.

Седло. Рассмотрение предметов повседневного конского снаряжения, изображенных на произведениях искусства, начнем с изображений седла. Очень подробно показано повседневное седло на парных золотых пластинах- 

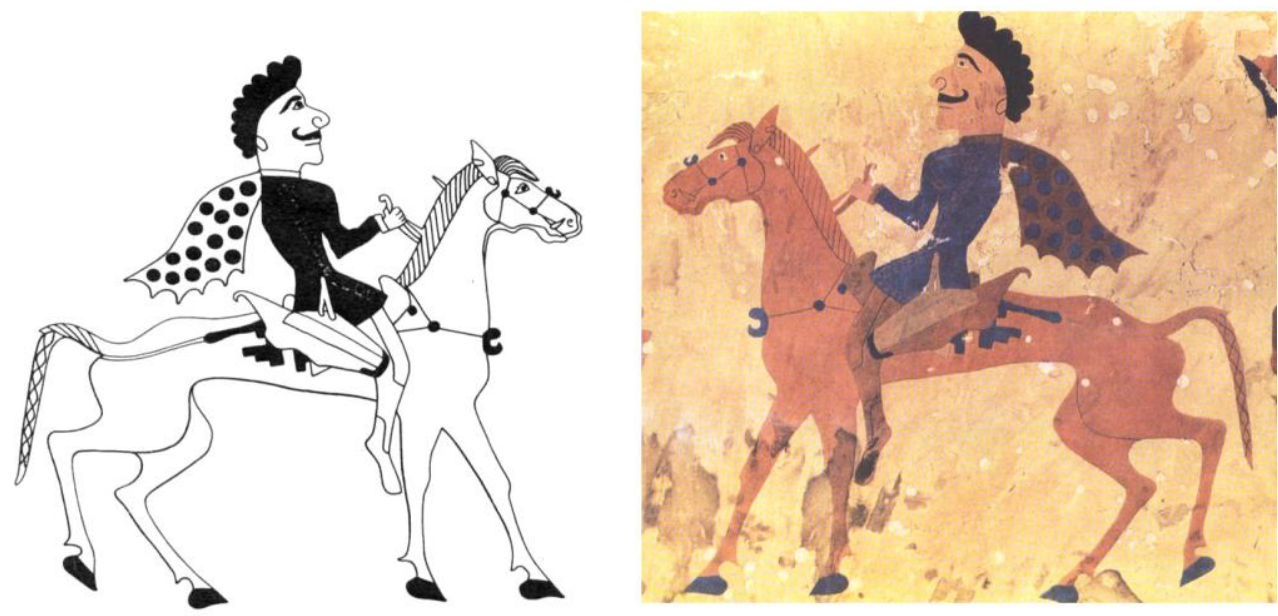

1
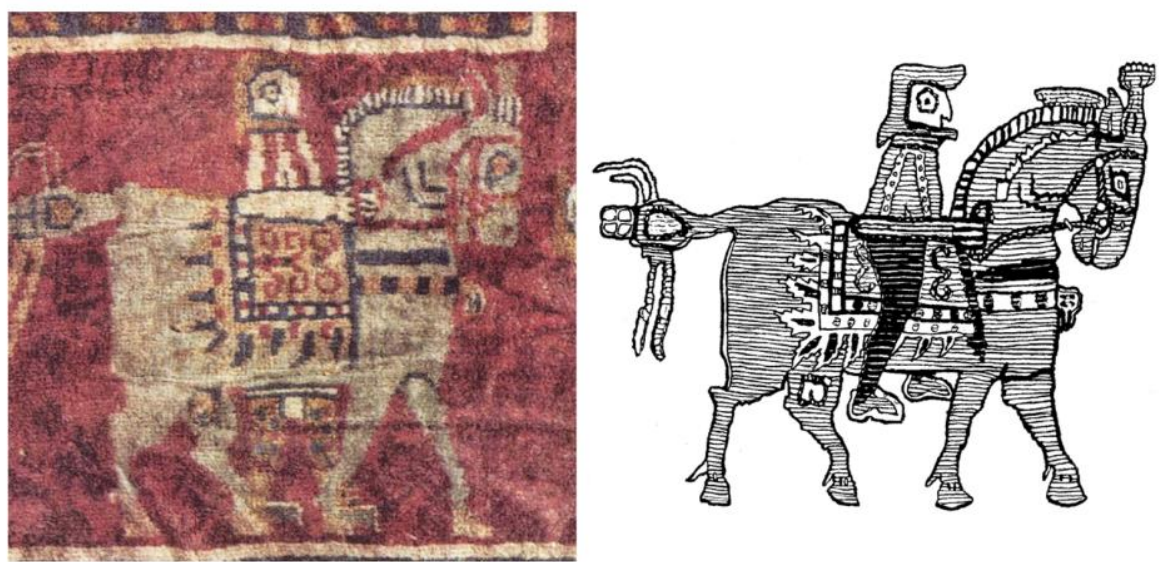

2

Рисунок 5. Мягкое седло сакского времени. 1, 2 - Изображение сакского всадника на войлочном ковре из Пятого Пазырыкского кургана. Государственного Эрмитажа. Санкт-Петербург. V-III вв до н.э. 3, 4 - Изображение всадников на ворсовом шерстяном ковре из Пятого Пазырыкского кургана. Государственного Эрмитажа. Санкт-Петербург. V-III вв до н.э.
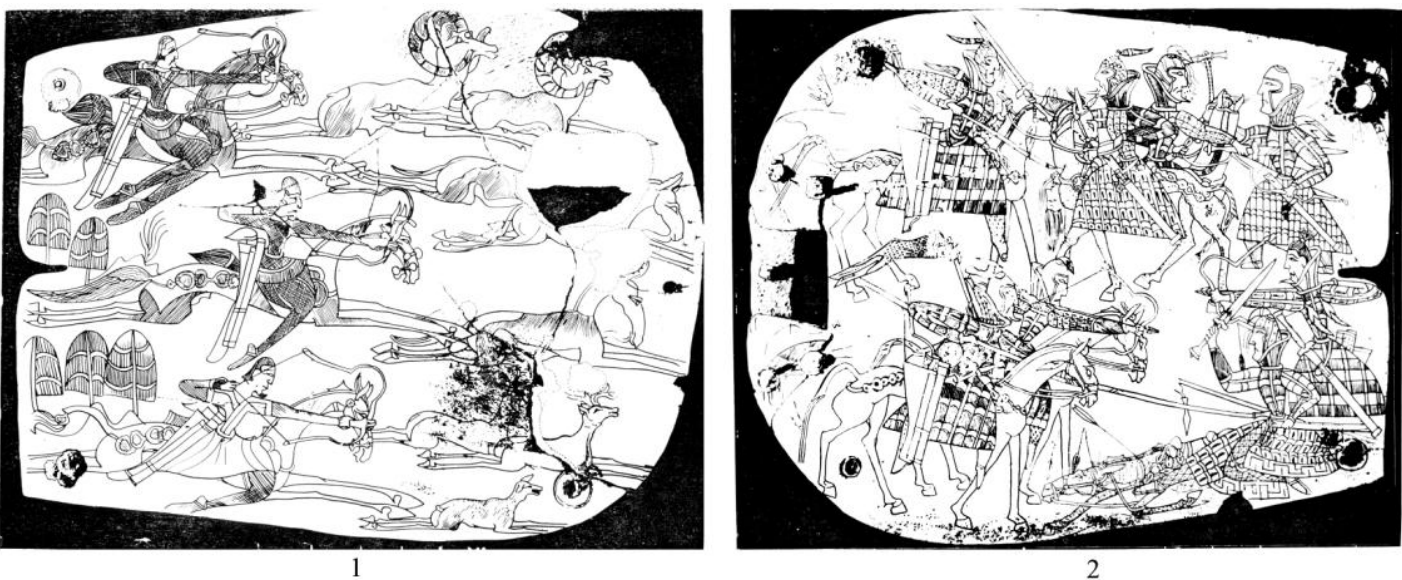

Рисунок 7. Костяные поясные пластины из Орлатского кургана №2, в Самаркандской области. III-II вв. до н.э. По Г.А. Пугаченковой 

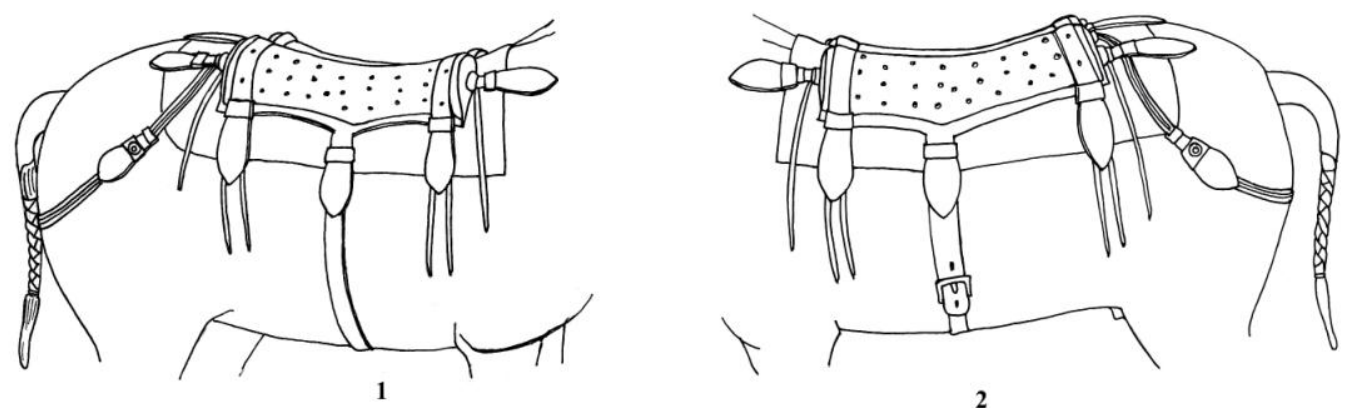

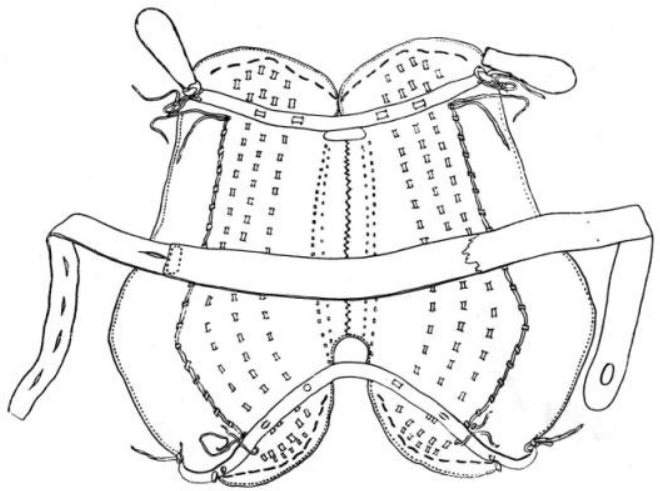

3

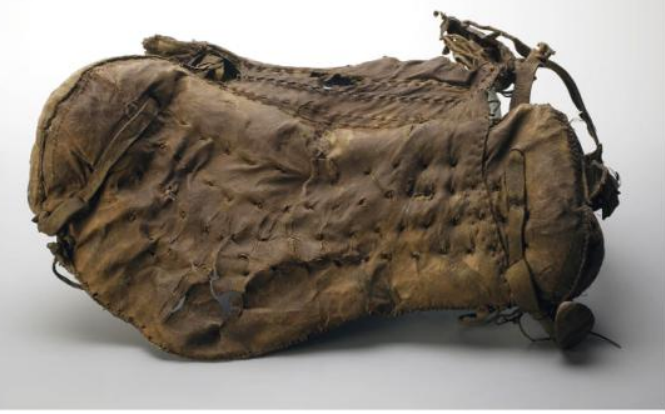

Рисунок 6. Мягкое седло сакского типа. 1, 2 - Изображение седла на терракотовых скульптурах коней из гробницы императора Цин Шихуанди. Китай, III в. до н.э.

3 - Мягкое кожаное седло из Первого Туэктинского кургана (по С.И. Руденко). 4 - Мягкое кожаное седло из Первого Туэктинского кургана. Государственный Эрмитаж. СанктПетербург. VI-V вв до н.э. Из сайта Государственного Эрмитажа
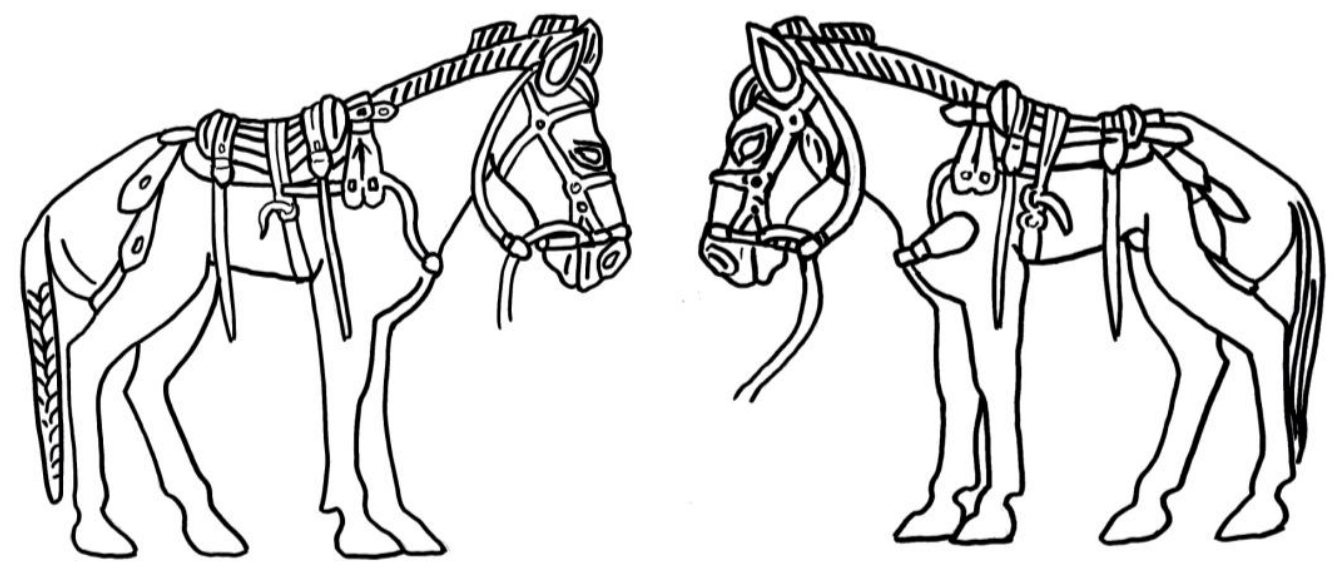

Рисунок 8. Прорисовка изображений оседланных лошадей на парной пластине-застежке из Сибирской коллекции Петра I. 1 - изображение на левой пластине. 2 - изображение на правой пластине. Прорисовка автора

${ }^{1} \mathrm{https}: / /$ www.hermitagemuseum.org/wps/portal/hermitage/digital-collection 
застежках из Сибирской колллекции Петра I, с изображением отдыхающих под деревом людей (Рисунок 8). При внимательном рассмотрении хорошо видно, что это типичное сакско-скифское мягкое седло, состоящее из двух кожаных подушек. Такие седла из двух, сшитых из кожи, мягких подушек были найдены в Пазырыкских, Башадарских, Туэктинском, Ак-Алахинских и Берельских курганах (Руденко 1953; 1960; Полосьмак 1994; 2001; Самашев 2011). Длина подушек около 50-58 см. Каждая из седельных подушек сшивалась из двух больших лоскутков кожи, образующих верхнюю и нижнюю поверхности, и двух малых, прикрывающих переднюю и заднюю поверхности подушек. Подушки набивались для мягкости оленьим волосом, шерстью, а иногда травой. Чтобы волос или трава, которыми набивались эти подушки, лежали ровным слоем, они простегивались крупным стежком тремя-четырмя продольными швами, шерстяным, конопляным, волосяным шнуром или кожаным ремешком. Как делались эти простежки можно увидеть на седле, которое было найдено Первом Туэктинском кургане (Рисунок 6:3,4) и на седле скульптурного изображения лошади из гробницы императора Цинь Шихуанди (Рисунок 6:1,2). Подушки-седла были широкими в средней части и слегка сужались к передним и задним краям. Широкая часть седла находился не точно в середине, а ближе к передней части. Обе подушки кожаным ремешком сшивались вместе внутренними краями. Поверх подушек особыми ремешками, пропущенными сквозь толщу подушек вдоль переднего и заднего краев, закреплялись по два ремня, в середине один широкий подпружный ремень. К этому верхнему подпружному ремню привязывался нижний подбрюшный ремень (Руденко 1953, С.161-164). Эти седла имеют уже сложившиеся передние и задние луки, сформированные из передних и задних поверхностей подушек. Е.В. Степанова называет этот элемент мягких седел «упорами», а не «луками седла» (Степанова 2003, С.152,153). Во многом соглашаясь с этим автором, мы все же традиционно сохраняем название «луки седла», потому что одна из функций лук и поздних жестких седел была служить упором для всадника. У разных народов в разное время появление разнообразных форм седельных лук было напрямую связано с усилением или уменьшением этой функции упора в зависимости от способа езды, назначения седел (военного, бытового, половозрастного и др.). Луки седла также простегивались ремешками в верхней части, создавая его кромку.

На седле, изображенном на пластине-застежке со сценой отдыха, ясно показаны продольные швы, простегивающие заполнения подушек, а валикообразные формы на подушках, образованные от этой продольной стежки, свидетельствуют о плотном их заполнении. Очень выпуклые передние и задние луки седла, изображенного на пластине-застежке, и линия, изображающая поперечный шов по верхнему краю лук, свидетельствуют что эти луки седла также внутри плотно заполнялись волосом и простегивались. По высоте лук, изображенное на застежке седло можно отнести ко второму типу пазырыкского седла, по типологии Руденко. Высота лук пазырыкских седел этого типа была в среднем около $10 \mathrm{~cm}$, ширина у основания - до 20 см и более. Луки некоторых седел из Башадарского кургана доходили до 12-15см (Руденко 1953, С.165; Руденко 1960, С.70). В отличии от парадных седел (исследованных археологически), покрытых сверху войлочными покрышками, имеющих роговые и деревянные украшения с рельефной резьбой, покрытых золотой фольгой или покрашенных в разные цвета, повседневное седло (изображенное на лошади из пластины-застежки), видимо, изготавливалось полностью из кожи.

Седла лошадей, изображенных на Ордосских костяных поясных пластинах, такой же конструкции, только на них не обозначены продольные простегивания 

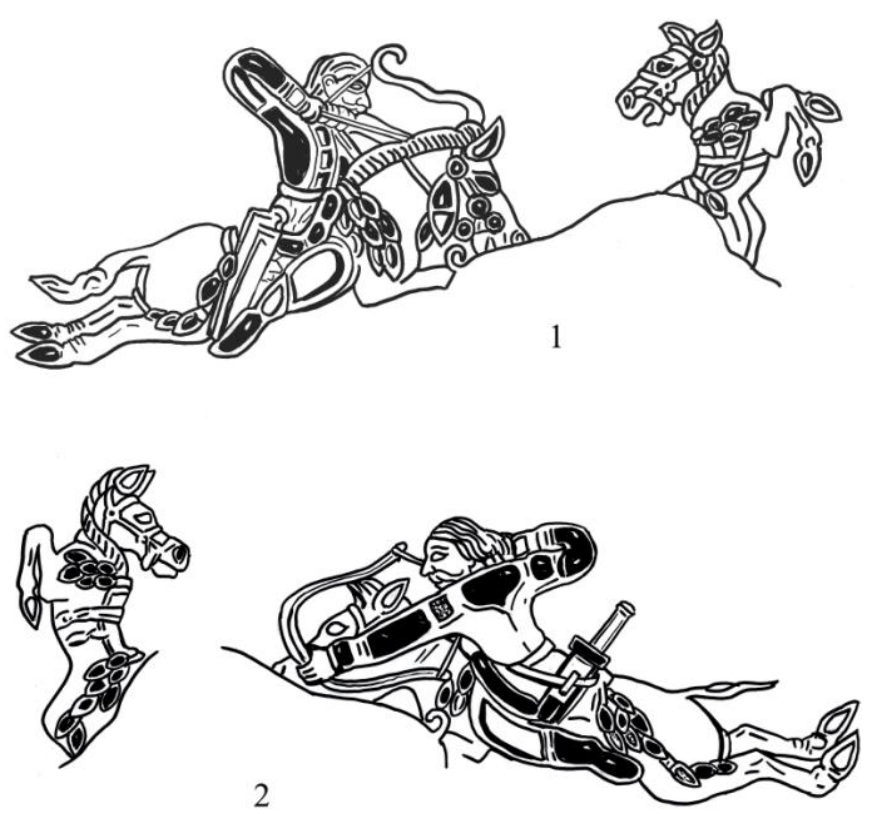

Рисунок 9. Прорисовка изображений оседланных лошадей на парной пластине-застежке из Сибирской коллекции Петра I.

1 - изображение всадника и вздыбленого коня на левой пластине. 2 - изображение всадника и вздыбленого коня на правой пластине. Прорисовка автора кожаных подушек и передних, задних лук седел (Рисунок 10). Небольшая высота их лук и отсутствие валикообразности от простегивании седельных подушек сближает их с седлами, изображенными на скульптурах лошадей из гробницы императора Цинь Шихуанди (Рисуноки 6.1, 6.2). Одно такое седло китайского типа с плоскими подушками и невысокими луками было найдено и в Пятом Пазырыкском кургане (Степанова 2003, С.152; 2014, С.235, 236).

Под седлом, изображенных на всех пластинах имеется войлочный потник, который несколько шире и длиннее седла. В археологических седлах потники вырезаны из белого плотного войлока, подшивались под седло и составляли с ним одно целое (Руденко 1953, С.161-164). Поверх потника под седло клали войлочную, ковровую или тканевую попону, края которой оформлялись ступенчатыми фестонами (Рисунок 5:2)

Седла, изображенные на пластинах-застежках, закреплены на спине лошади с помощью подпруги. Подпруга седла на золотой пластине-застежке с изображением сцены отдыха под деревом, состоит из двух частей - верхнего и нижнего подпружных ремней (Рисунок 8). По верху седла (в его широкой части) проходит верхний подпружный ремень или приструга, которая пришита ремешками к седельным подушкам. Вдоль ремня по середине проходит шов. Это свидетельствует о том, что ремень сшит из сложенной вдвое полосы кожи. На концах верхнего подпружного ремня закреплены подпружные кольца, куда завязаны концы нижнего подпружного ремня. Около седельных лук, поперек подушек проходят такие же широкие ремни, которые скрепляют кожаные подушки, они на концах тонкими ремешками пришиты к седельным подушкам. Поперечные седельные ремни также имеют продольный шов - видимо, тоже сшиты из сложенных вдвое широкой полосы кожи.

Подвески. На концах этих поперечных седельных ремней имеются кожаные шлевки и щитовидные подвески. Под щитовидными подвесками к ремням привязаны длинные приторочные ремни - тороки, которые в виде узкого ремня спускаются ниже живота лошади. Подвески размером чуть поменьше, но более удлиненной формы закреплены в середине передних и задних лук. Подвески были необходимым функциональным элементом, поэтому они объязательно имелись на концах различных седельных ремней. На археологических седлах 
подвески на концах поперечных ремней удерживали ремень пропущенную через шлевки. В небольших подвесках у передних и задних лук, проходя внутри подушек, узлом закреплялись концы ремешков продольной простежки подушек седла (Руденко 1953, С.161164.). Подобные кожаные щитовидные подвески имелись на седлах, найденных в пазырыкских курганах. На парадных седлах из этих курганов на кожаные подвески пришивались роговые щитовидные бляшки или декоративные деревянные щитовидные накладки с различными изображениями, покрашенные или покрытые золотой фольгой. Тут надо заметить, что мягкое седло, изображенное на памятниках скифского искусства, не имеет продольного простегивания, изображается с низкими луками и только с

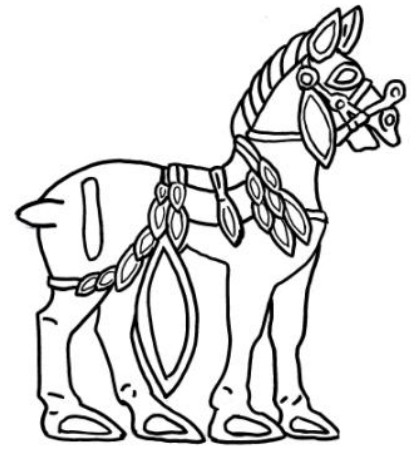

1

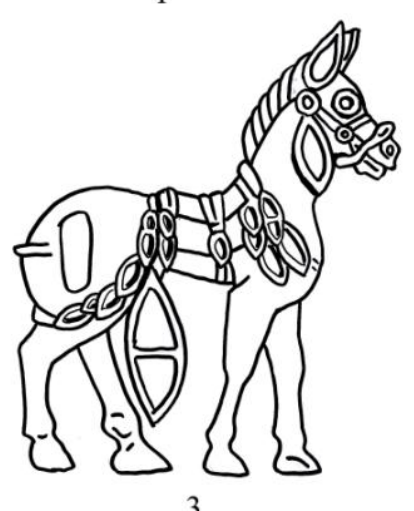

3

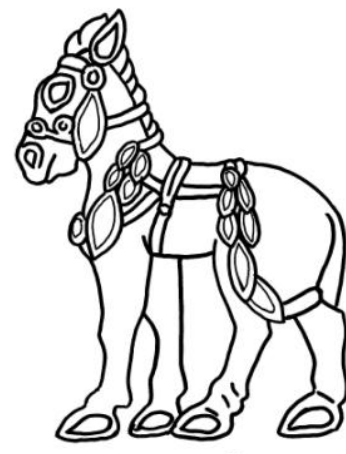

2

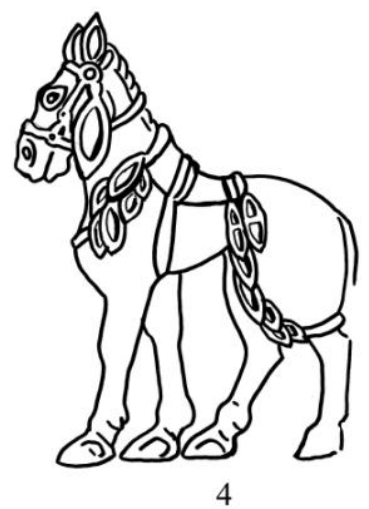

4

Рисунок 10. Прорисовка изображений оседланных лошадей на бронзовых поясных пластинах из Ордоса. 1 прорисовка левой лошади из пластины. 2 - прорисовка правой лошади из пластины. По Пугаченковой. Прорисовка автора

подпружными ремнями, без поперечных седельных ремней, поэтому не имеет таких подвесок (Рисунок 14:3). Видимо, это более ранняя фрорма скифосакского мягкого седла, которую скифы унесли с собой и сохранили во время своего продвижения на запад. О простегиваниях и поперечных ремнях, которые появились на востоке позже, после ухода скифов, и применялись восточными кочевниками, скифы, видимо уже не знали, но зато хорошо были знакомы таким типом седла и переняли его кочевые племена, жившие по соседству с ними на севере Китая. Седла такого кочевнического типа изображены на спинах коней терракотовой армии древнекитайского императора Цинь Шихуанди, раскопанных в 1979 г. (The First Emperors Terracotta Legion 1988, Р.129, 130-1, т. 112, 114). На них четко изображено продольное простегивание подушек, но луки этих седел низкие, подушки плоские и соответствуют первому типу пазырыкского седла (Рисунок 6.1, 6.2). По мнению 3. Самашева, эти кони, возможно, принадлежали воинам-кочев-никам, служившим в цинской армии (Самашев 2011, С.154). На седле скульп-туры лошади из гробницы китайского императора Цинь Шихуанди очень под-робно изображены шлевки и удлиненно-щитовидные подвески на концах попе-речных седельных ремней, верхнего подпружного ремня, в середине передних и задних лук.

Если подвески на концах поперечных сдельных ремней, изображенных на пластине-застежке со сценой отдыха под деревом имеют щитовидную форму, 


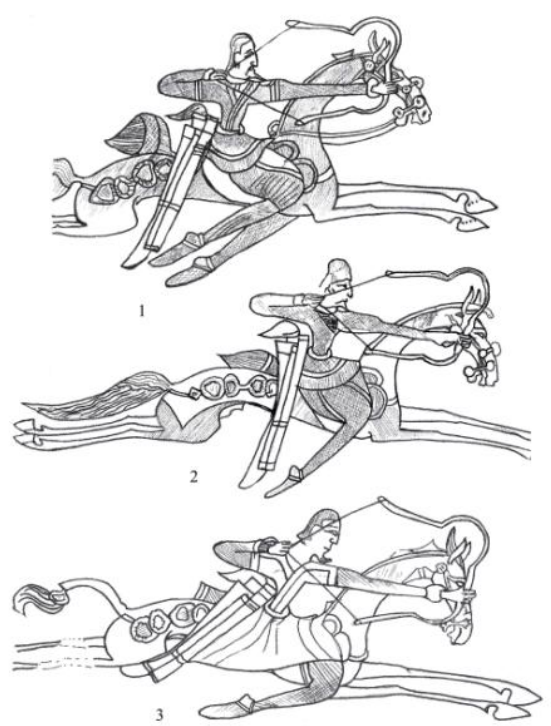

Рисунок 11. Кангюйцы на охоте. Из изображений

на костяной поясной пластине из кургана Орлат. Прорисовка автора
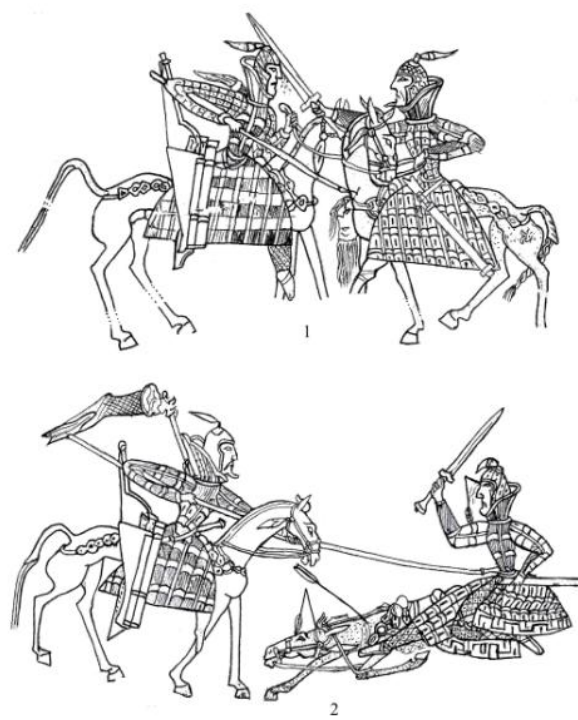

Рисунок 12. Сражающиеся кангюйцы. Из изображений

на костяной поясной пластине из кургана Орлат. Прорисовка автора то на другой паре золотых пластин-застежек из Сибирской коллекции Петра I с изображением сцены охоты на кабана (Рисунок 9), а также на поясных пластинах из Ордоса (Рисунок 10) они имеют листовидную форму и состоят из нескольких звеньев (от 2-3 штук) таких подвесок. Кроме того, в повседневных седлах, изображенных на этих и других произведениях искусства древних кочевников, к такой цепочке из нескольких звеньев подвесок прикреплены нагрудные и подхвостные ремни.

Подхвостный ремень. Подхвостный ремень седла у всадника, изображенного на пазырыкском войлочном ковре состоит из трех частей - двух удлиненных лопастевидных ремней с расширенным щитовидным концом и закрепленном на задней луке седла (эта часть подхвостника покрашена в синий цвет) и завязанным на них узкой полосы ремня, проходящей под хвостом лошади (Рисунок 5:1). Аналогичными были подхвостники, найденные в пазырыкских курганах (Рисунок 13:1). Как показали археологические материалы появление лопастевидной части подхвостника было связано с его практическим назначением. Разделение подхвостных ремней на три части давало возможность, связывая эти части, сокращать или удлинять их в соответствии с размером тела лошади, таким образом регулируя его длину при практическом применении. Поэтому для закрепления узкого основного ремня подхвостника на конце другого ремня подхвостника, укрепленного на задней луке седла, конец этого ремня нужно было немного расширить. И эти концы получили расширяющуюся к концу лопастевидную форму. На конце этого лопастевидного расширения делались два прореза, и узкий ремень подхвостника, проходя через них, завязывался на его обратной стороне. Таким образом, завязанный узел узкого подхвостного ремня скрывалася внизу под ремнем широкой лопастевидной формы. Такими были подхвостные ремни пазырыкских седел, которые также состояли из трех частей (Рисунок 13:2,3). В парадных седлах, найденных в Пятом Пазырыкском кургане, на лопастевидные части, в виде подвесок, подхвостных ремней сверху пришивались удлиненные, расширенные к низу деревянные пластины-накладки и подвески щитовидной формы, украшенные изображениями распластанного кошачьего хищника и его головы, покрытыми золотой фольгой (Рисунок 13:1) (Руденко, 1953, С.168,169). Например, на скульптуре лошади из гробницы Цинь Шихуанди узкая ременная часть подхвостника седла закреплена на такой щитовидной подвеске (Рисунок 8:1,2). 


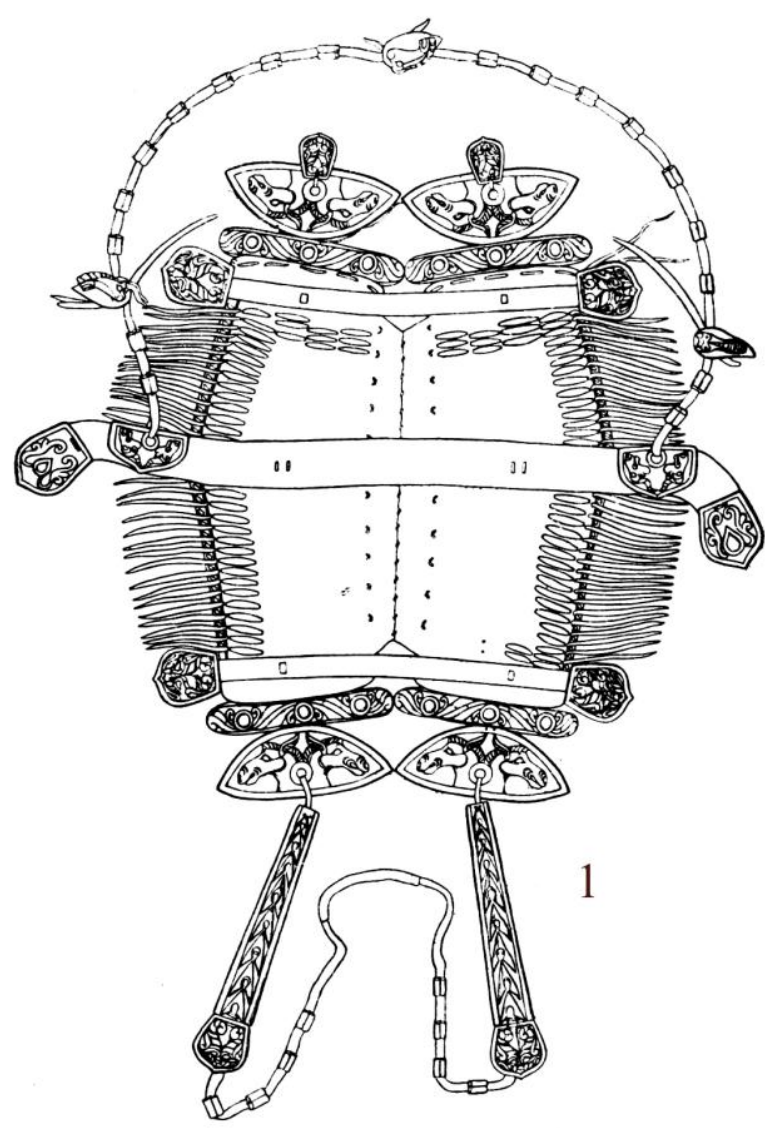

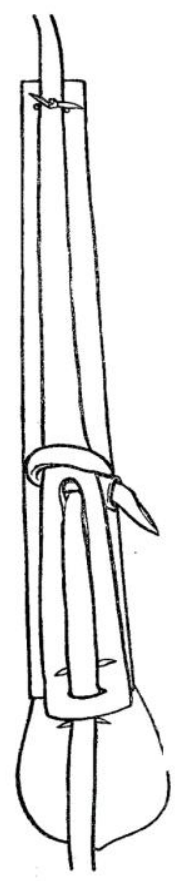

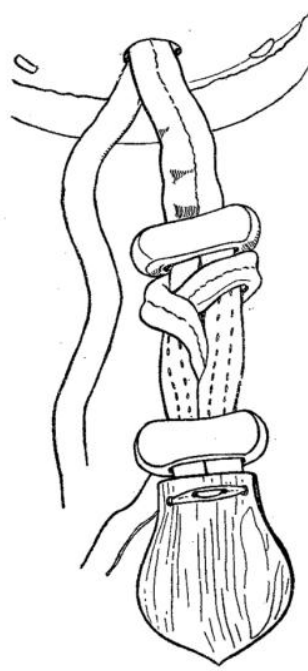

3

Рисунок 13. Подхвостный ремень сакского седла. 1 - Оформление подхвостного ремня седла из Пятого Пазырыкского кургана.

2,3 - Схема соединения частей подхвостника. По С.И.Руденко

Подобная конструкция была основой, из которой в дальнейшем создавались разнообразные усложненные варианты подхвостника на бытовых седлах древних кочевников. Например, подхвостный ремень седла, изображенного на пластине-застежке с изображением отдыха под деревом также состоит из трех основных частей: двух-трех звеньев удлиненных, расширяющихся кожаных лопастей-подвесок, закрепленных на задних луках седла и узкого ремня, который проходит под хвостом лошади. Так как пластины-застежки отливались по форме или штамповались, (а фрормы употреблялись, возможно, много раз, что приводило к огрублению изображения) их края теряли четкости, и это затрудняет пониманию их конструкций, и поэтому в публикациях прорисовка этих элементов часто дается неправильно. При более четкой и правильной прорисовке видно как звенья из лопастей соединены друг с другом, проходя узкими концами сквозь два отверстия-прорези на широком конце другой лопасти, как подхвостные ремни седла из Пятого Пазырыкского кургана (Рисунок 8, Рисунок 13).

Лопасти-подвески подхвостного ремня седла на лошади охотника, изображенного на другой золотой пластине-застежке (сизображением охоты на кабана) из Сибирской коллекции Петра I состоит уже из нескольких (5-7 штук) звеньев небольших лопастей-подвесок листообразной фрормы (Рисунок 9). Способы их соединения между собой не прорисованы, потому что лопасти-подвески ремня сделаны в виде бирюзовых вставок, которые, возможно, имитируют синий цвет кожи лопасти, как на седле всадника из Пазырыкского войлоч- 
ного ковра. Изготовление лопастевидной части подхвостного ремня из нескольких звеньев лопастей-подвесок, видимо, продиктовано не практическими задачами, а художественно-эстетическими. К ним закреплен узкий основной ремень подхвостника.

Подобной формы подхвостный ремень у седел лошадей борющихся войнов был изображен на бляшках, найденных в Ордосе (Северный Китай). Подхвостники этих седел также состоят из трех частей: из нескольких (до 6-ти) звеньев, постепенно увеличивающихсяв размере, листо-видных лопастейподвесок, закрепленных на задних луках и узкого ремня в виде полосы (Рисунок 10). Способы их соединение не прорисованы. Но нет со-мнения, что они анологичны способу, изображенному на пластине-застежке со сценой отдыха под деревом. Эти лопасти-подвески изображаются по краям с выпуклым валиком. В оригинале, служившем прототипом для их воспроизведения, видимо, внутри них была вставка из цветных камней или стекол, как на пластине застежке со сценой охоты из Сибирской коллекции Петра І. На всех изображениях подхвостный ремень завязан более свободно и слегка свисает с крупа лошади.

Нагрудный ремень. Если описанные выше подхвостные ремни повседневных седел, изображенных на пластинах, схожи по конструкции и отличаются лишь количеством звеньев лопастей-подвесок, то нагрудные ремни седел, изображенных на произведениях искусства разного времени более разнообразны по конструкции. Нагрудный ремень седла, изображенного на войлочном ковре из Пазырыка состоит из трех узких ремней - длинного основного и двух коротких нахолкных, как на синхронных археологических седлах, и соединены между собой круглой бляхой (Рисунок 5, 1). Но нагрудный ремень седла, изображенный на золотой пластине-застежке со сценой отдыха под деревом, имеет очень сложную форму. Он состоит из четырех частей - серединной, нахолкной и двух концевой. Серединная часть нагрудного ремня на двух концах имеет расширение лопастообразной формы, возможно, в виде подвески, на них закреплены два более узких концевых ремня, которые проходят через прорези на двойных лопастевидных концах (или подвесках) нахолкного ремня, перекинутые через холку лошади, и другими своими концами закреплены на верхнем подпружном ремне седла.

Нагрудный ремень на лошадях охотников, изображенных на золотой пластине-застежке со сценой охоты из Сибирской коллекции, состоит из трех небольших лопастей-подвесок листообразной фрормы, которые, возможно, закреплены на передих луках. Способы их соединения между собой не прорисованы, потому что лопасти ремня сделаны в виде бирюзовых вставок, которые, возможно, имитируют цвет кожи лопастей-подвесок (Рисунок 9). Подобной фоормы нагрудный ремень седла на лошадях, изображен на поясных пластинах, найденных в Ордосе (Рисунок 10). Только подвески немного увеличиваются в размере к груди лошади. Способ их соединения не прорисован. Но нет сомнения, что они анологичны способу соединения лопастей-подвесок подхвостников описанных выше.

Таким образом, как видим, если на изображении IV-III в. лопасть-подвеска под-хвостника толька одна, то в изображении III века уже их несколько. Видимо, древние мастера исходя из художественных задач, при изготовлении нагрудного и подхвостного ремней их лопастевидные части стали делать в виде цепочки из нескольких звеньев лопастей-подвесок, создавая декоративную фрорму. Это в свою очередь привело к тому, что кроме практического назначения лопастевидная форма подвесок концов ремней седельных принад- 
лежностей стала применяться также и как декоративное оформление. Таким способом в виде нескольких звеньев лопастей-подвесок стали оформляться и концы поперечных седельных ремней, для создания художественной цельности всего седельного комплекта. Этого требовали также и законы композиции художественной формы. Поэтому иногда такое оформление в виде лопастейподвесок из нескольких звеньев можно видеть и на концах верхнего подпружного ремня (Рисунок 4).

Некоторые исследователи изображения этих лопастей-подвесок на нагрудниках и подхвостниках принимают за кисти, что мы считаем ошибочным. Это хорошо видно на изображениях подхвостников и нагрудников на седлах лошадей охотников и воинов, изображенных на поясных костяных пластинах из Орлатского кургана №2. Их подхвостники и нагрудники также состоят из нескольких звеньев лопастей-подвесок и завязанного на нем узкого ремня (Рисунок 11 и Рисунок 12). Что это не кисти, а плоские кожаные лопасти, хорошо видно в сравнении их изображений с изображением кистей на шлемах, на горитах воинов, а также по способу их соединения между собой. Г.А. Пугаченкова изображенных на пластине ситает кангюйцами, и датировку пластин определяет III-II веками до н.э (Пугаченкова 1987, С. 62,63). То есть по времени они близки к ордосским и сибирским пластинам. Седло кангюйцев тоже было мягким седлом пазырыкского типа, это можно видеть на изображении седла лежащей раненной лошади на пластине с изображением сцены битвы воинов (Рисунок 12, 2). На тахтисангинских костяных пластинах (Литвинский 2002, С.182,183, Рисунок 1-3), синхронных орлатским, прорисовки седел и подхвостных, нагрудных ремней не четки, из-за стертости изображения, но, видимо, и они были подобной конструкции, как на выше описанных произведениях искусства.

Седельная подвеска. Еще одним периферийным элементом древнего седла кочевников была большая седельная подвеска, свисающая сбоку лоша-ди. Такие парадные, богато украшенные седельные подвески разной формы, изготовленные с применением войлока, кожи, дерева найдены в пазырыкских, акалахских, берелских курганах. Изображения на произведениях искусства показывают, что в нарядных бытовых седлах также иногда применялись такие
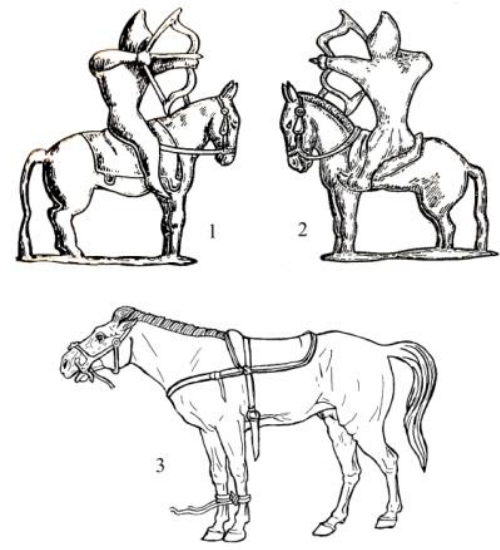

Рисунок 14. Бытовое конское снаряжение кочевников разных времен.

1, 2 - Хуннский всадник. Бронзовая скульптура из Ордоса. Северный Китай. По Ю.С.Худякову.

3 - Скифское мягкое седло. Фрагмент изображения на серебряной вазе. Прорисовка автора большие седельные подвески, которые свисали сбоку лошади почти до земли. Большая седельная подвеска листовидной фрормы имеется на некоторых седлах лошадей, изображенных на бронзовых поясных пластинах из Ордоса с изображением борющихся воинов (Рисунок 10, 1,3; Рисунок 4). Листовидная фоома этой подвески, видимо, была продиктована единством художественного решения всего седельного комплекса, на которых концевые лопасти-подвески седельных ремней имели формы листа. Большие седельные подвески для легкости, видимо, изготавливались из войлока как на пазырыкских седлах. Седельный комплект с большими седельными подвесками был более усложненным вариантом повседневного седельного комплекса. 

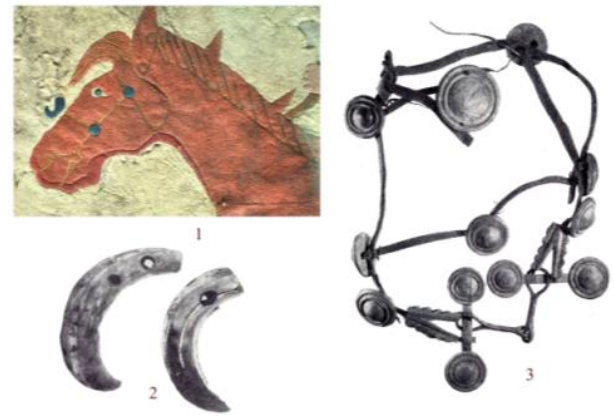

Рисунок 15. Сакская узда. 1 - фрагмент изображения на войлочном ковре из Пятого Пазырыкского кургана. 2 - кабаньи клыки, укашения узды. Второй Башадарский курган. 3 - конская узда. Пятый

Пазырыкский курган. По С.И. Руденко.

Узда. Повседневная конская узда очень схожа по конструкции с изображениями на всех вышерассмотренных памятниках искусства. Узда состоит из суголовного, нащечного, налобного, подбородного ремней и ремня переносья. Места соединения всех этих ремней на изображениях прикрыты круглыми бляшками (бронзовыми или деревянными?) полусферической формы или с полусферическим выступом в середине. Нащечный ремень на конце раздваивается и крепится на псалии, на месте раздвоения ремня также изображается круглая бляшка. Форма псалий почти прямоугольная, с очень слабым изгибом концов или в виде круглых бляшек, как на местах соединения ремней узды. Узда, оформленная с такими круглыми бляшками на местах соединения ремней, с такими же концами псалий была найдена в Пятом Пазырыкском кургане (Рисунок 15:3) (Руденко 1953, табл. XLVIII). В Пазырыкских и Башадарских курганах сохранились также и такие отдельные деревянные круглые бляшки конской узды (Руденко, 1960, С.44, 45, рис.20.е). К псалиям с правой стороны прикреплялся один конец повода, а левой стороны прикреплялся чумбур, а к нему на специальном блоке крепился другой конец повода. На изображениях иногда узда на месте соединения суголовного, нащечного и налобного ремней украшалась большой подвеской листовидной формы. Такую подвеску можно видеть на узде лошадей, изображенных на парных пластинах-застежках со сценой охоты на кабана (Рисунок 9:1), а также на уздечках лошадей, изображенных на поясных пластинах из Ордоса (Рисунок 10). Этот способ украшения узды в древности у кочевников был, видимо, очень распространенным. Такую декоративную лопасть-подвеску небольшого размера имеет узда на бронзовой скульптуре хуннского всадника из Ордоса (Рисунок 14:1,2). На орлатских пластинах узда на этом месте украшена кистью (Рисунок 12). На изображении всадника на войлочном ковре из Пятого Пазырыкского кургана на ремне переносья узды и на нагрудном ремне коня изображены кабаньи клыки, которые прикреплялись в защитных магических целях (Рисунок 5:1; Рисунок 15:1). Такие кабаньи клыки или их имитации из дерева, принадлежавшие к конскому снаряжению часто встречаются в археологических материалах (Рисунок 15:2) (Башадарский курган, Пазырыкский курган).

Подводя итоги, можно сказать, что схожесть повседневного бытового конского снаряжения на разных изображениях, выполненных на разных материалах, в разное время, разными мастерами доказывает существование у родственных древних кочевых племен Восточного Казахстана, Южного Казахстана и Средней Азии, Алтая, Северного Китая единой традиции, единой технологии их изготовления в течение двух-трех и более столетий. Повседневное снаряжение верхового коня у древних кочевников состояло из узды с поводьями и чумбуром, мягкого седла с нагрудным и подхвостным ремнями, полностью изготовленных из кожи, без особых украшений. На концах поперечных седельных ремней и верхнего подпружного ремня-приструги надевались кожаные шлевки и закреплялись кожаные подвески щитовидной, листовидной 
или округлой формы. Для красоты иногда на концах седельных ремней крепились несколько таких подвесок, соединенные в виде цепочки из звеньев. Для удобства регулировки длины подхвостный ремень изготавливался из нескольких частей: удлиненной лопастевидной кожаной подвески со шлевком. Эта часть подхвостника изготовливалась иногда для красоты. Ее тоже делали из нескольких звеньев лопастей-подвесок, соединенных в цепочку, и узкого ремня, который проходя через прорезы на широком конце подвески, завязывался под ней. Таким же образом изготавливался и нагрудный ремень, он дополнительно удерживался нахолкным ремнем. Иногда к седлу по бокам, около задних лук крепили большие войлочные седельные подвески листовидной формы. Узда на местах соединения налобного, суголовного, нащечного ремней украшалась круглыми бляшками с полусферическим выступом в середине, по бокам нащечный ремень украшался большой листовидной или щитовидной подвеской или кистью.
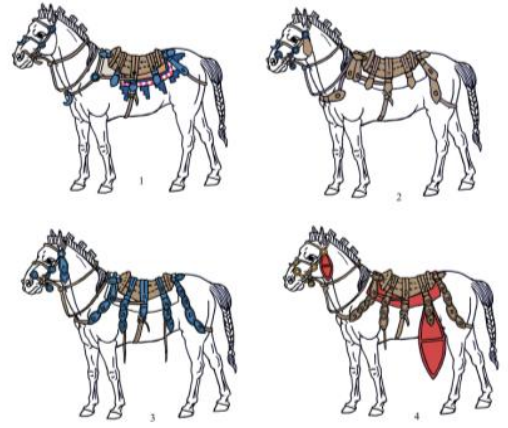

Рисунок 16. Реконструкция разных

вариантов повседневного комплекта конского снаряжения древних кочевников. 1 - IV в. до н.э. 2 - III в. до н.э. 3,4 - II в. до н.э. Рисунок автора
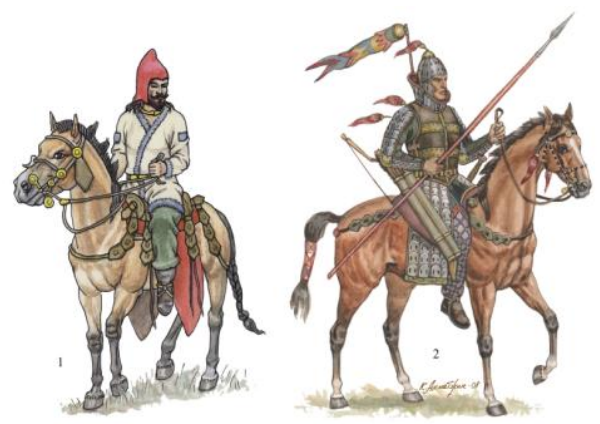

Рисунок 17. Всадник-кочевник на коне с повседневным конским снаряжением. 1 - Сакский всадник. 2 - Всадник кангюй. Реконструкции автора по изобразительным материалам

Разные варианты повседневного комплекта конского снаряжения, реконструированные по изображениям на произведениях искусства древних кочевников представлены на Рисунках 16 и 17. Сравнение их с археологическими материалами показывает, что эти комплекты повседневного снаряжения стали основой для парадных церомониальных и ритуальных конских снаряжений, которые пышно украшались декоративными накладками, войлочными покрышками, декоративными подвесками и при погребениии знатных воинов и вождей хоронились вместе с ними.

\section{Әдебиеттер тізімі/ Список литературы}

1. Артамонов М.И. Сокровища саков. - М.: Искусство, 1973. - 280 с.

2. Грязнов М.П. Древнейшие памятники героического эпоса народов Южной Сибири // Археологические сообщения Государственного Эрмитажа. Вып. 3. Эпоха бронзы и раннего железа Сибири и Средней Азии. - Л.: Издательство Государственного Эрмитажа, 1961. - С.7-31. 3. Литвинский Б.А. Бактрийцы на охоте // Записки Восточного отделения Российского археологического общества (ЗВОРАО). - Т.I(XXVI). - СПб: «Петербургское Востоковедение», 2002 - С.181-213.

4. Полосьмак Н.В. Всадники Укока. - Новосибирск: ИНФОлИО-пресс, 2001. - 336 с.

5. Полосьмак Н.В. «Стерегущие золото грифы» (Ак-Алахинские курганы). - Новосибирск: ВО «Наука», 1994. - 125 с.

6. Пугаченкова Г.А. Из художественной сокровищницы Среднего Востока. - Ташкент: Изд-во лит. 
и искусства, 1987. - 224 с

7. Рец К.И Поясные пластины со сценой охоты на кабана из Сибирской коллекции Петра I: к вопросу о хронологической и культурной атрибуции // Босфорский феномен: проблемы хронологии и датирования памятников. Материалы международно научной конференции. - Ч.2. СПб: Из-во Государственного Эрмитажа, 2004. - - С. 325-332.

8. Руденко С.И. Культура населения Горного Алтая в скифское время. - М.: Издательство Академии наук СССР, 1953. - 392 с.

9. Руденко С.И. Культура населения Центрального Алтая в скифское время. - М.-Л.: Наука, 1960. - 360 c.

10. Руденко С.И. Сибирская коллекция Петра І. Археология СССР. САИ. Вып. Д3-9. - М.-Л.: Издво Академии наук СССР, 1962. - 52 с. 27 табл.

11. Самашев 3. Берел. - Алматы: Таймас, 2011. - 236 б.

12. Степанова Е.В. Скифские мягкие сёдла: вопросы терминологии // Степи Евразии в древности и средневековье. Книга II. Материалы научно-практической конференции, посвящённой 100летию со дня рождения М.П. Грязнова. - СПб: Издательство Государственного Эрмитажа, 2003. 310 c. (C. $151-154)$

13. Степанова Е.В. Седла из Третьего Пазырыкского кургана // Культура степной Евразии и их взаимодействие с древними цивилизациями. - Кн.2. - СПб: НИМК РАН, «Периферия», 2013. C.446-454.

14. Степанова Е.В. Китайские седла III в. до н.э - III в. н.э.// Труды IV(XX) Всероссийского археологического съезда. - СПб.: Государственный Эрмитаж, 2014. - С.235 -240.

15. So J.F., Bunker E.C. Traders and raiders on Chinas nordern frontier. - Seattle: Universiny of Washington Press, 1995. - 204 p.

16. The First Emperors Terracotta Legion. - Beijing: China Travel and Tourism Press, 1988. - 205 p.

\section{Reference}

Artamonov 1973 - Artamonov, MI 1973, Sokrovishcha sakov, Iskusstvo, Moskva, 280 s. (Artamonov, MI 1973, Treasures of the Saks, Iskusstvo, Moskow, 280 p). (in Rus).

Gryaznov 1961 - Gryaznov, MP 1961, Drevnejshie pamyatniki geroicheskogo ehposa narodov YUzhnoj Sibiri, Arheologicheskiy sbornik gosudarstvennogo Ehrmitazha. Vyp. 3. EHpoha bronzy i rannego zheleza Sibiri i Srednej Azii, Izdatel'stvo Gosudarstvennogo EHrmitazha, Leningrad, S.7-31 (Gryaznov, MP 1961, The most ancient monuments of the heroic epic of the peoples of Southern Siberia, the Archaeological collection of the State Hermitage. Issue. 3. The era of bronze and early iron in Siberia and Central Asia, the State Hermitage Publishing House, Leningrad, P.7-31). (in Rus).

Litvinskij 2001 - Litvinskij, BA 2001, Baktrijcy na ohote,Zapiski Vostochnogo otdeleniya Rossijskogo arheologicheskogo obshchestva (ZVORAO),Tom I(XXVI), «Peterburgskoe Vostokovedenie», Sankt-Peterburg, S.181-213. (Litvinskij, BA 2001, Bactrians on the hunt, Notes of the Eastern Branch of the Russian Archaeological Society (ZVORAO), Tom I(XXVI), «Peterburgskoe Vostokovedenie», Sankt-Peterburg, P.181-213). (in Rus).

Polos'mak 1994 - Polos'mak, NV 1994, "Steregushchie zoloto grify» (Ak-Alahinskie kurgany), Novosibirsk, VO «Nauka», 125 s. (Polos'mak, NV 1994, «Protecting gold vultures» (Ak-Alakhinsky mounds), Novosibirsk, VO «Nauka», 125 p). (in Rus).

Polos'mak 2001 - Polos'mak, NV2001, Vsadniki Ukoka, INFOLIO-press, Novosibirsk, 336 s. (Polos'mak, NV 2001, The horsemen of Ukok, INFOLIO-press, Novosibirsk, 336 p). (in Rus).

Pugachenkova 1987 - Pugachenkova, GA 1987, Iz hudozhestvennoj sokrovishchnicy Srednego Vostoka, Izd-vo lit. i iskusstva, Tashkent, 224 s. (Pugachenkova, GA 1987, From the art treasury of the Middle East, Izd-vo lit. i iskusstva, Tashkent, 224 p). (in Rus).

Rec 2004 - Rec, KI 2004, Poyasnye plastiny so scenoj ohoty na kabana iz Sibirskoj kollekcii Petra I: k voprosu o hronologicheskoj i kulturnoj atribucii, Bosporskij fenomen: problemy hronologii $i$ datirovaniya pamyatnikov. Materialy mezhdunarodno nauchnoj konferencii, CH.2, Iz-vo Gosudarstvennogo EHrmitazha, Sankt-Peterburg, S.325-332.(Rec, KI 2004, Belt plates with a boar hunting scene from the Siberian collection of Peter I: to the question of chronological and cultural attribution, Bosporus phenomenon: problems of chronology and dating of monuments. Materials of an international scientific conference, Part 2, From the State Hermitage Museum, Saint-Petersburg, P. 325-332). (in Rus).

Rudenko 1953 - Rudenko, SI 1953, Kul'tura naseleniya Gornogo Altaya v skifskoe vremya, Izdatel'stvo Akademii nauk SSSR, Moskva, 392 s. (Rudenko, SI 1953, Culture of the Altai population in Scythian time, Publishing House of the USSR Academy of Sciences, Moscow, 392 p). (in Rus).

Rudenko1960 - Rudenko, SI 1960,Kul'tura naseleniya Central'nogo Altaya v skifskoe vremya, Nauka, Leningrad, 360 s. (Rudenko, SI 1960, Culture of the population of Central Altai in Scythian time, Nauka, Leningrad, 360 p). (in Rus). 
Rudenko 1962 - Rudenko, SI 1962, Sibirskaya kollekciya Petra I. Arheologiya SSSR. SAI. Vyp. D3-9, Izd-vo Akademii nauk SSSR, Moskva-Leningrad, 52 s. (Rudenko, SI 1962, Siberian Collection of Peter I. Archeology of the USSR. AIS. Issue. D3-9, USSR Academy of Sciences, Moscow Leningrad, 52 p.). (in Rus).

Samashev 2011 - Samashev, Z 2011, Berel, Tajmas, Almaty, 236 b. (Samashev, Z 2011, Berel, Tajmas, Almaty, 236 p). (in Kaz).

Stepanova 2003 - Stepanova, EV 2003, Skifskie myagkie syodla: voprosy terminologii,Stepi Evrazii v drevnosti i srednevekov'e. Kniga II. Materialy nauchno-prakticheskoj konferencii, posvyashchyonnoj 100-letiyu so dnya rozhdeniya M.P. Gryaznova, Izdatel'stvo Gosudarstvennogo EHrmitazha, Sankt-Peterburg, S. 151-154.(Stepanova, EV 2003, Scythian soft saddles: questions of terminology, Steppes of Eurasia in antiquity and the Middle Ages. Book II. Materials of the scientific-practical conference dedicated to the 100th anniversary of the birth of M.P. Gryaznova, Publishing house of the State Hermitage Museum, Saint-Petersburg, P. 151-154). (in Rus).

Stepanova 2013 - Stepanova, EV 2013, Sedla iz Tret'ego Pazyrykskogo kurgana,Kul'tura stepnoj Evrazii $i$ ih vzaimodejstvie $s$ drevnimi civilizaciyami, Kn.2, «Periferiya», NIMK RAN, SanktPeterburg, S.446-454.(Stepanova, EV 2013, Saddles from the Third Pazyryk Barrow, Culture of the Steppe Eurasia and their interaction with ancient civilizations, Kn.2, «Periferiya», NIMK RAN, Saint-Petersburg, P.446-454). (in Rus).

Stepanova 2014 - Stepanova, EV 2014, Kitajskie sedla III v. don.eh - III v. n.eh.,Trudy IV(HKH) Vserossijskogo arheologicheskogo s"ezda, Gosudarstvennyj EHrmitazh, Sankt-Peterburg, S.235 240. (Stepanova, EV 2014, Chinese saddles of the 3rd c. don - e - III century. AD, Proceedings of the IV (XX) All-Russian Archaeological Site, the State Hermitage Museum, Saint-Petersburg, P.235 -240). (in Rus).

So, Bunker1995 - So, JF, Bunker, EC 1995, Traders and raiders on Chinas nordern frontier, Universiny of Washington Press, Seattle, 204 p. (So, JF, Bunker, EC 1995, Traders and raiders on Chinas nordern frontier, Universiny of Washington Press, Seattle, 204 p). (in Eng).

The First Emperors Terracotta 1988 - The First Emperors Terracotta Legion 1988,China Travel and Tourism Press, Beijing, 205 p. (The First Emperors Terracotta Legion 1988, China Travel and Tourism Press, Beijing, 205 p). (in Rus). 